\title{
Raising more domestic money for health: prospects for low- and middle-income countries
}

\author{
RIKU ELOVAINIO \\ World Health Organization, Egypt Country Office, Cairo, Egypt \\ DAVID B. EVANS* \\ Health Systems Research and Dynamic Modelling Group, Swiss Tropical and Public Health Institute, Basel, \\ Switzerland \\ University of Basel, Basel, Switzerland
}

\begin{abstract}
Since the 2007/2008 financial crisis, the rhetoric in the development assistance dialogue has shifted away from raising more international funding for health, to requesting countries to move toward self-sufficiency. This paper examines the potential of 46 countries identified by an international panel in 2009 as being of high need to raise additional funding for health from domestic sources. Economic growth alone would allow 12 of them to reach a level of health spending where their populations could have access to a very basic set of health services. All of them have the potential to raise additional domestic funds through a range of measures that have been tried successfully in other low- and middle-income countries, but they would all remain well below the eventual objective of universal health coverage without increased and predictable external financial support.
\end{abstract}

\section{Introduction}

All countries face a constant struggle to secure sustainable and sufficient funding of their health systems. Even the richest countries have found it difficult to keep up with rising health care costs even before the current economic downturn, which put further pressure on health spending. A report focusing on Europe concluded that a number of countries had seen their health budgets cut since the financial crisis hit in 2007/2008 - some substantially; in Iceland, total government health expenditure per capita shrank by 13\% between 2008 and 2010, in Latvia government spending on health prevention and promotion activities fell by $89 \%$ over the same period (Mladovsky et al., 2012).

*Correspondence to: David Evans, Department of Health Systems Research and Dynamic Modelling, Swiss Tropical and Public Health Institute, Socinstrasse 57, 4051 Basel, Switzerland. Email: david.evans@unibas.ch 
The absolute shortage of funds is much more acute, however, in low- and middle-income countries. Although the current international economic turmoil has affected their economic growth much less than in the high-income countries and they have received substantial inflows of development assistance for health (DAH) since the Millennium Declaration was signed in 2000, they still spend too little to assure their population access to even a minimum set of health services. In 2009, the High Level Taskforce on Innovative International Financing for Health Systems (HLTF) estimated that low-income countries ${ }^{1}$ would need to spend an annual average ${ }^{2}$ of $\$ 60$ per capita on health by 2015 in order to ensure coverage with a set of key health services, largely focusing on the conditions targeted by the Millennium Development Goals (MDGs) for health. The target is the very minimum necessary because the core set of interventions included only limited care and prevention for non-communicable diseases (NCDs) and it was assumed that the entire sum would be spent efficiently. As we are today in the era of the Sustainable Development Goals (SDGs), the funding needs will need to be updated based on the SDG health targets. This health SDG costing work is currently ongoing.

In the first article of this series, McIntyre et al. (2017) have made the arguments of setting government health expenditure targets at $5 \%$ of gross domestic product (GDP) and at US\$86 per capita. These targets emerge from several sources, including from the HLTF calculations. This paper looks more directly at the 46 HLTF countries ${ }^{3}$ for which good enough data exists in order to establish a benchmark of the magnitude of the gap between the estimated cost of a package of health services, as defined in the HLTF calculations, and what these low- and middle-income countries can probably mobilize from domestic resource in the short term.

In second section we describe current spending patterns and then project how domestic health spending might evolve as a result of economic growth. In third section we ask how countries could improve their revenue raising for health. First looking at what would happen if countries chose to spend a higher proportion of their available resources on health, and then turn to different options for raising additional revenue for health domestically, independent of economic growth.

While raising more money for health is crucial, the available resources must also be used efficiently and equitably. This paper focuses only on the possibilities of raising additional domestic funds for health, but it is important to emphasize that moving toward universal health coverage will not only require more money, but also more value for money and active consideration of the equity implications of different ways of using the available resources (Ottersen et al., 2014).

1 The HLTF analysis included countries classified as 'low income' by the World Bank as of June 2007.

2 All averages are unweighted averages unless otherwise noted.

3 The countries are listed in Appendix 1. 


\section{Health expenditure trends and cross-country analysis}

Cross-country comparisons suggest that total health spending per capita grows with national income per capita, illustrated in Figure 1. This is not deterministic, however. Some countries spend appreciably more than expected given their income level, and some considerably less. Even allowing for macroeconomic constraints, policy choices matter; health expenditure is determined by the capacity and desire of governments to raise revenues and by the willingness and ability of households, firms and governments to contribute and then to spend the available funds on health (Savedoff, 2007; Xu and Saksena, 2011).

Domestic funds for health are either paid directly to health providers for the services that are received or are channeled through pooling mechanisms which spread the financial risks of ill health across the population. When pooling systems are weak, people are forced to pay for services out of their own pockets. Out-of-pocket spending (OOPs) for health leads to financial catastrophe and impoverishment for some people who need to use health services, while it deters others from seeking or continuing treatment.

In Figure 2, total health expenditure (THE) is divided into the shares derived from OOPs and from prepaid and pooled funds, respectively, for the 46 countries (including external funding which by definition is considered pooled funding).

At the two extremes, in six of the 46 countries prepaid and pooled funds represent more than $80 \%$ of THE (Gambia, Haiti, Malawi, Mozambique, Papua New Guinea and Solomon Islands), while in four they are less than 30\% (Afghanistan, Myanmar, Sierra Leone and Yemen). Prepaid and pooled funds in most of the 46 countries consist primarily of government health expenditures and compulsory

(a)
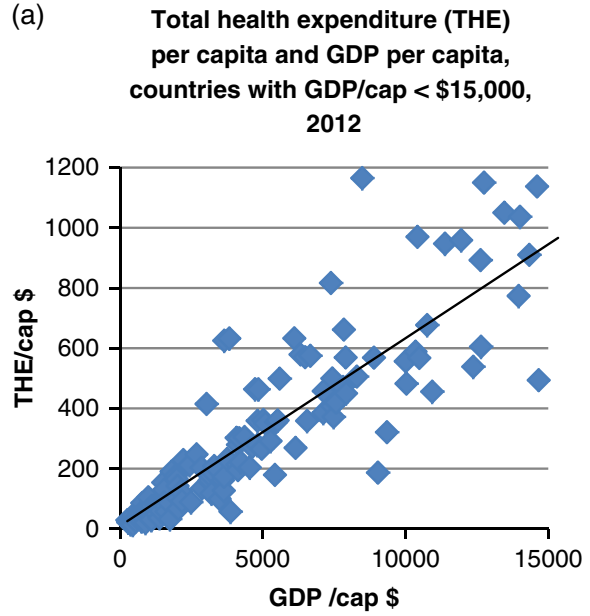

(b)

Total health expenditure (THE) per capita and GDP per capita, all countries, 2012

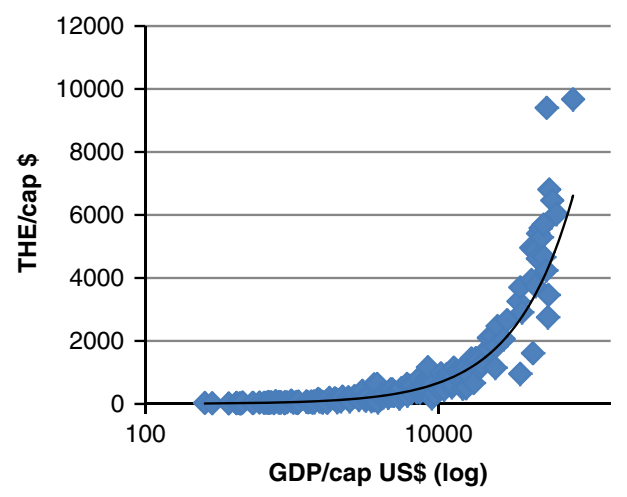

Figure 1. Total health expenditure (THE) per capita and gross domestic product (GDP) per capita (a) in countries with GDP per capita under $\$ 15,000$ (b) in all countries (logarithmic scale). Source: WHO, Global Health Expenditure Database. 


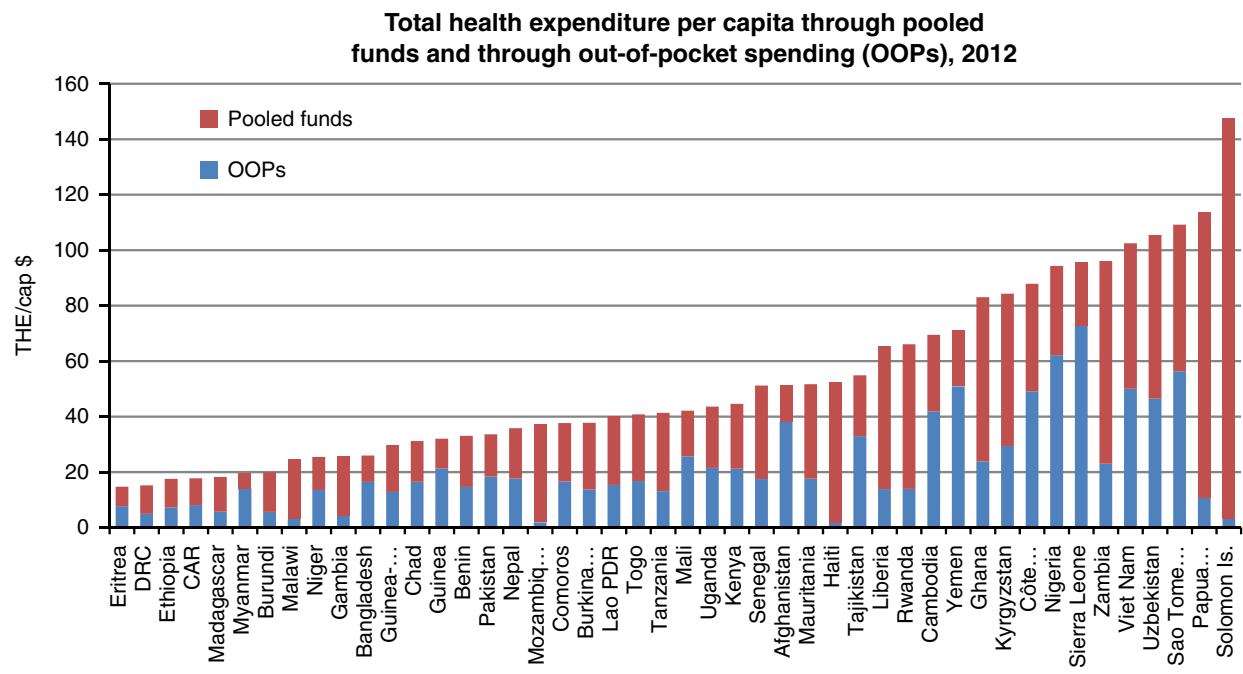

Figure 2. Per capita total health expenditure (THE) from out-of-pocket spending (OOPs) vs per capita health expenditure from pooled funds.

Source: WHO, Global Health Expenditure Database.

health insurance [the combination is called general government health expenditure (GGHE)]. Funds from external sources, channeled through GGHE or implemented through non-governmental organizations form a large share of pooled funds in many of the poorest countries. Private health insurance (including voluntary community health insurance) represents only $1.3 \%$ of THE in these countries although the range is quite wide with many having zero or close to zero spending on private health insurance, while at the other extreme, in Kenya and Senegal the share of private health insurance in THE is 6 and 9\%, respectively.

Governments' abilities to spend on health are influenced by their capacity to raise public revenues, reflected in the overall level of general government expenditure (GGE). Figure 3 reports GGE per capita (on everything, not just health) for our 46 countries, and GGE as a share of GDP. For 30 of the countries, GGE is below $30 \%$ of GDP: for five it is less than $20 \%$.

There are no clear benchmarks for what the share of government spending in national income should be. In the EU countries, for example, GGE/GDP varies from 30 to $59 \%$ (European Commission, 2012). It is more difficult to raise revenues, notably through direct income taxes, in countries with large informal sectors, one of the reasons why GGE/GDP is frequently lower in low-income countries. Figure 3 shows that in many of the countries under discussion GGE/GDP was well below the $30 \%$ minimum observed in the EU countries, suggesting that there is scope to raise more revenues over time given their levels of GDP. To illustrate, the International Monetary Fund (IMF) compared countries' fiscal potential with their actual government revenues, finding that low-income 


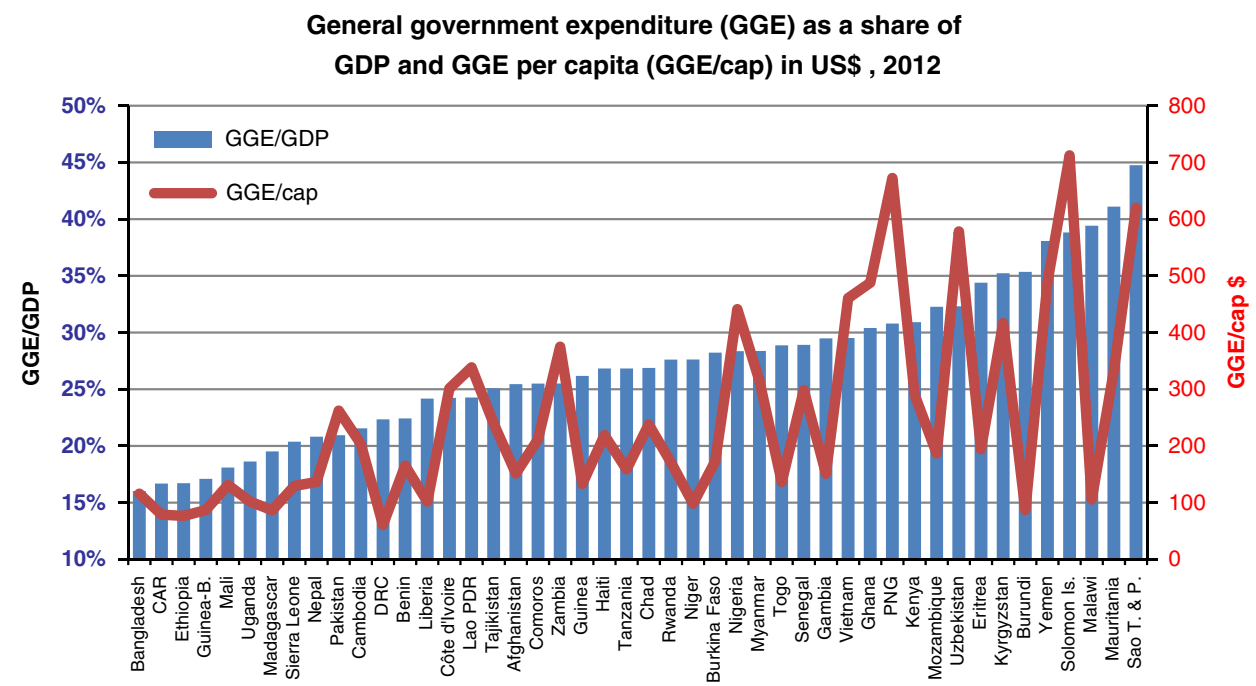

Figure 3. General government expenditure (GGE) per capita and as a share of gross domestic product (GDP).

Source: WHO, Global Health Expenditure Database.

countries reach on average only $78 \%$, and lower-middle-income countries $63 \%$ of their potential (estimated through an assessment of the size and structure of the economy) for mobilizing government revenues (IMF, 2011).

The GGE/GDP ratio does not reveal the whole picture of resource availability. In five of the 13 countries that have a GGE/GDP ratio of $30 \%$ or more, per capita GGE is still below $\$ 300$. This money has to be distributed across all sectors, not just health. If a country spending $\$ 300$ GGE per capita allocated $15 \%$ to health, as suggested in the Abuja Declaration for countries that are members of the African Union, GGHE would still reach only $\$ 45$ per capita, showing the limits imposed by low absolute levels of national income and a low government share of the economy.

While the revenue raised by governments limits their overall capacity to spend, the priority they give to health when allocating the available resources varies considerably. Figure 4 shows that the share of GGHE in GGE is below $10 \%$ for more than half of the 46 countries (24), and in four it is even below $5 \%$. In only 10 is GGHE per capita more than $\$ 30$ and the average government health spending per capita is only $\$ 25$ for the countries as a whole. This figure includes funding from external sources channeled through government (it is not possible to extract external sources), so the level of government health spending from domestic resources is in most cases lower.

\section{Projections of total health spending}

We now turn to the question of the potential for these countries to raise additional revenues for health in the future, initially focusing only on the impact of 
General government health expenditure (GGHE) as a share of GGE and GGHE per capita, 2012

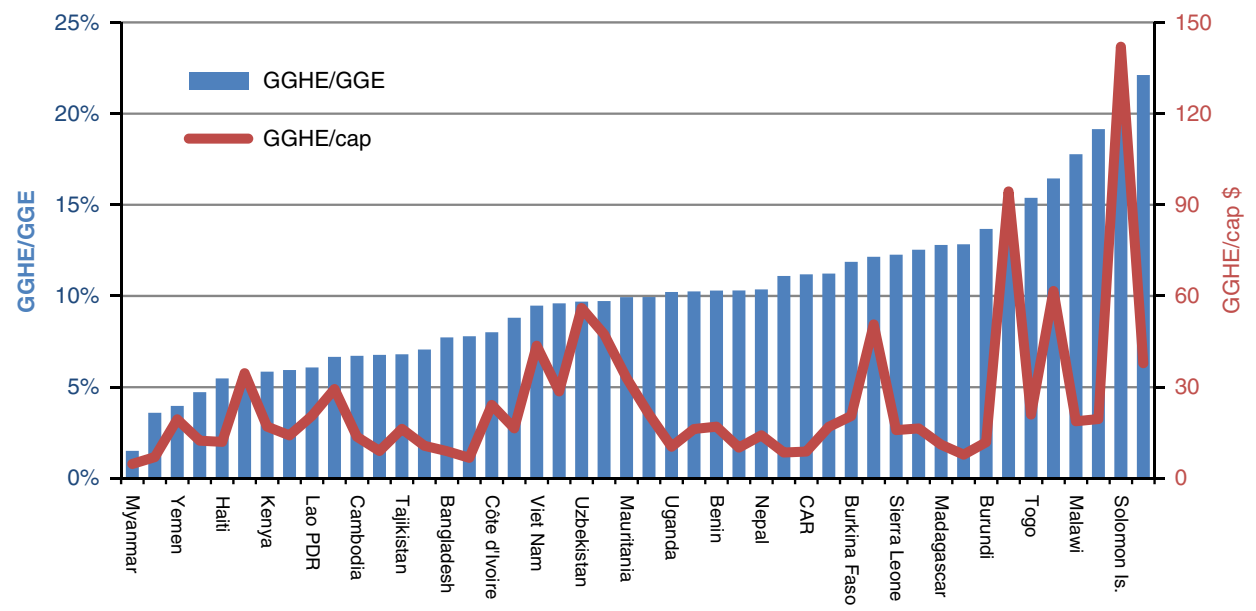

Figure 4. Priority of health in general government expenditure (GGE).

Source: WHO, Global Health Expenditure Database.

Note: GGHE = general government health expenditure.

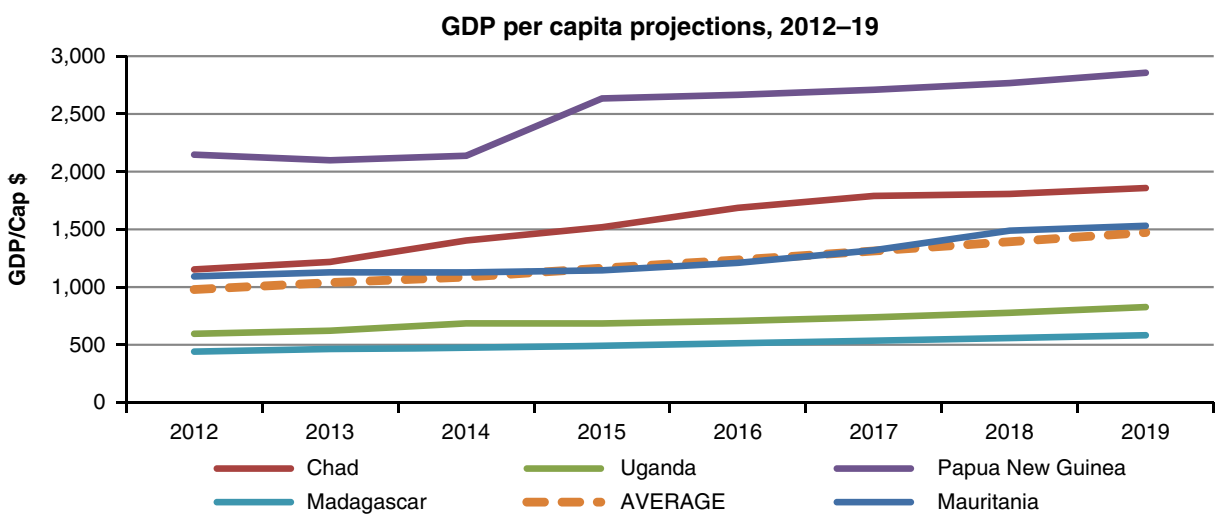

Figure 5. Projected gross domestic product (GDP) per capita growth in five countries and average for the 46 countries.

Source: IMF, World Economic Outlook Database, April 2012 edition.

economic growth. The IMF projects that GDP per capita will grow at an average rate of 3.4\% per year between 2012 and 2019 in the set of countries that we are following (IMF, 2014). Growth is expected to vary, however, across these countries. Figure 5 shows the projected rates for Chad, Madagascar, Mauritania, Papua New Guinea, Uganda and Viet Nam (two rapid-growth, one average and two lower-growth countries). For example, in 2012 Chad and Uganda had a \$550 difference in GDP per capita, a difference projected to increase to \$1000 in 2019. 
To examine the effect only of economic growth, we assume that nothing changes in terms of shares of GGE in GDP, of GGHE in GGE and of government health expenditure in GDP, nor in the amount of external inflows. THE from domestic sources would increase by $\$ 20$ billion in the 46 countries between 2012 and 2017 through domestic economic growth alone. This represents an average increase of $\$ 8.3$ per capita between 2012 and 2017, and would allow THE per capita from domestic sources to reach on average $\$ 45$ by 2015 and $\$ 49$ by 2017 (see Figure 6). This is still lower than the $\$ 60$ per capita the HLTF estimated would be needed by 2015 for even a minimum set of key health services. Looking at the country level HLTF targets, 12 of the 46 countries would reach their own 'need' targets (ranging from \$21to \$146) for THE by 2015 from domestic sources through economic growth alone. The others have little realistic chance of reaching the levels required from domestic growth even if THE tends to, though not always, increase as a share of GDP over time. As yet, no good estimates exist of the cost of reaching the SDG health targets, but given that these health targets are more ambitious than those in the MDGs, it is safe to assume that the funding needs will be higher than we assume above. Our estimates, therefore, can be considered the most optimistic possible.

If we add to our projections of domestically sourced expenditures for 2015 the current 2012 levels of DAH, another four countries would reach their HLTF target, leaving 30 under their desirable 2015 spending levels - many of them substantially under. The HLTF argued that the inescapable conclusion is that if the global community is serious about helping these countries achieve internationally accepted targets in health, it is important not just to maintain current levels of DAH but to increase them.

It needs to be underlined that the projections discussed above are on THE. The core policy issue when linking the need to increase resources for health to the universal health coverage (UHC) objective lies in the way OOPs can be crowded

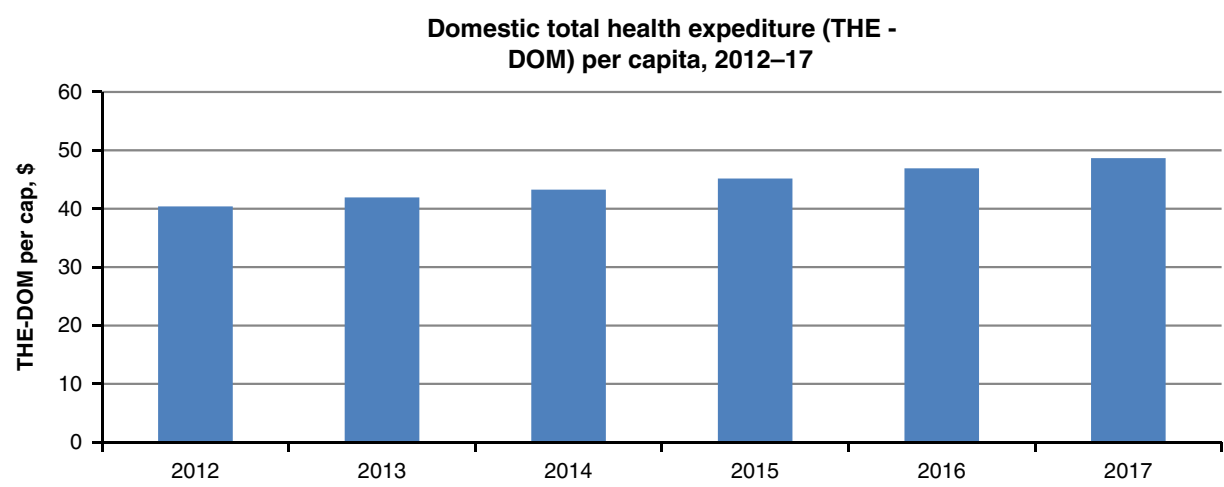

Figure 6. Projections of growth of total health expenditure (THE) per capita from domestic sources - average of the 46 countries.

Source: WHO, Global Health Expenditure Database. 
out by GGHE (and, in some extents by external funding). The UHC imperative of reducing OOPs will open many streams of discussions on health financing system reform which we are not going to tackle in full in this article but which we are going to approach from the point of view of increasing domestic pooled funding for health in the following section.

\section{Increasing domestic funding for health: options}

There are many ways countries could raise additional revenues for health, summarized in Table 1 . These options were chosen not because they could work in theory, but because some low- and middle-income countries have actually done them, countries listed in the last column. We briefly discuss these options in this section.

\section{Increasing the share of existing government revenues allocated to bealth}

The share of government revenue spent on health is one indication of government commitment to health. In Figure 7 we use the data reported in Figure 5 to map GGHE/GGE against GDP per capita. For the 46 countries, the share of total government spending allocated to health varies from 1.5 to $22 \%$ (including external funding flowing through government). GGHE/GGE is not highly correlated with GDP per capita suggesting that it is not necessary to wait for national income to grow before a higher proportion of government revenues can be allocated to health.

Allocating a higher share of government spending to health has the potential to generate substantial additional funding. For the 46 countries, increasing GGHE/ GGE to $15 \%$ (the Abuja target) overnight would increase available health revenues by $\$ 25$ billion, or $\$ 18$ per capita using 2012 as the base year. ${ }^{4}$ If the $15 \%$ threshold were maintained to 2017, government health spending would grow by $\$ 34$ billion using the growth rates reported above. Again there is considerable variation across countries. Nigeria would contribute $\$ 3.7$ billion to this, allowing it to increase GGHE by $\$ 16$ per capita through the combined effect of economic growth and increased priority to health in public spending.

Increasing the share of government expenditure going to health is politically complex, illustrated by the fact that in the 10 years after the Abuja Declaration was signed, almost as many African Union countries moved away from the target of $15 \%$ as moved closer to it (WHO Regional Office for Africa, 2011; McIntyre et al., 2017). Yet, a number of low- and middle-income countries have shown that it is possible to increase the share of GGE going to health. In Viet Nam, the National Assembly promulgated laws guaranteeing increases in the health budget (Tien, 2011). The share of health in GGE increased from 5\% in 2004 to $9.5 \%$ in 2012. This was partly in response to reel back the liberalization policies of the 1980s and

4 Assuming that those currently over $15 \%$ will stay at their current level of GGHE/GGE. 
Table 1. Options for increasing domestic revenue for health beyond economic growth

\begin{tabular}{|c|c|c|c|}
\hline Revenue mobilization approaches & Possible actions and strategies & $\begin{array}{l}\text { Possible revenues generated } \\
\text { (in general and for health) }\end{array}$ & Country examples \\
\hline $\begin{array}{l}\text { Redistributing existing government } \\
\text { revenues to health or reducing } \\
\text { subsidies on other things (e.g. fossil } \\
\text { fuels) to spend on health }\end{array}$ & $\begin{array}{l}\text { Advocacy; creating political will; } \\
\text { demonstrating results; demonstrating } \\
\text { efficiencies }\end{array}$ & $\begin{array}{l}\text { If African Union countries would meet } 15 \% \\
\text { GGHE/GGE target they would increase health } \\
\text { expenditure by } \$ 29 \text { billion }\end{array}$ & $\begin{array}{l}\text { Chile, Indonesia, Iran (shifting from } \\
\text { fuel subsidy to social spending), } \\
\text { Rwanda, Viet Nam }\end{array}$ \\
\hline $\begin{array}{l}\text { Formalization of economies, tax } \\
\text { efficiency or expanded tax base }\end{array}$ & $\begin{array}{l}\text { Improving governance; enforcing existing } \\
\text { regulations; simplifying administrative } \\
\text { procedures and reforming tax collection } \\
\text { agencies }\end{array}$ & $\begin{array}{l}\text { Depends on country contexts, but formalization } \\
\text { could potentially increase GGE/GDP ratios by } \\
\text { several percentage points }\end{array}$ & $\begin{array}{l}\text { Indonesia, South Africa, Turkey, } \\
\text { Uganda }\end{array}$ \\
\hline $\begin{array}{l}\text { Increased taxation on natural } \\
\text { resources }\end{array}$ & $\begin{array}{l}\text { Good governance to avoid the 'resource } \\
\text { curse'; specific taxation measures on } \\
\text { 'super profits'b }\end{array}$ & $\begin{array}{l}\text { Context-specific; Botswana has shown that } \\
\text { significant amounts of revenue can be raised } \\
\text { with sound policies and transparency }\end{array}$ & $\begin{array}{l}\text { Botswana, Lao PDR, Papua New } \\
\text { Guinea }\end{array}$ \\
\hline $\begin{array}{l}\text { Increased taxation of harmful habits } \\
\text { and products (e.g. tobacco, } \\
\text { alcohol, drinks high in sugar) }\end{array}$ & $\begin{array}{l}\text { Advocacy on the 'win-win' nature of these } \\
\text { taxes; creating evidence on implications } \\
\text { on revenue and health outcomes }\end{array}$ & $\begin{array}{l}\text { Possibilities for increases especially for countries } \\
\text { with existing rates below regional averages; e.g., } \\
\text { Philippines, increased alcohol and tobacco taxes } \\
\text { to raise additional } \$ 3.4 \text { billion }=1.3 \text { times } \\
\text { current GGHE }\end{array}$ & $\begin{array}{l}\text { Djibouti, Egypt, Guatemala, Mexico, } \\
\text { Mongolia, Nepal, Philippines, } \\
\text { Thailand, Turkey, Tuvalu }\end{array}$ \\
\hline $\begin{array}{l}\text { Increased taxation on other types of } \\
\text { products/industries }\end{array}$ & $\begin{array}{l}\text { Obtaining support of powerful interest } \\
\text { groups; advocating toward corporations } \\
\text { that it is in their interest that government } \\
\text { can invest in public goods }\end{array}$ & $\begin{array}{l}1 \% \text { tax on turnover of companies that would } \\
\text { represent } 5 \% \text { of GDP, will yield } 0.05 \% \\
\text { of GDP in revenue }\end{array}$ & $\begin{array}{l}\text { Financial transactions } \\
\text { Argentina, Brazil } \\
\text { Luxury products } \\
\text { China, Indonesia, Viet Nam } \\
\text { Telephone Services } \\
\text { Gabon, Ghana, Senegal, Republic } \\
\text { of Congo, Uganda }\end{array}$ \\
\hline $\begin{array}{l}\text { Voluntary sources of revenue } \\
\text { (e.g. from businesses) }\end{array}$ & $\begin{array}{l}\text { Mobilizing private sector actors behind } \\
\text { public health goals; increase dialogue } \\
\text { with private sector actors }\end{array}$ & $\begin{array}{l}\text { Can provide catalytic resources and can } \\
\text { be used as leverage to raise other funds }\end{array}$ & $\begin{array}{l}\text { Corporate social responsibility } \\
\text { Malawi, Papua New Guinea, } \\
\text { South Africa } \\
\text { Diaspora bonds (increases domestic } \\
\text { funds from external sources) } \\
\text { India, Lebanon, Sri Lanka }\end{array}$ \\
\hline
\end{tabular}

Note: GGHE = general government health expenditure; GGE = general government expenditure; GDP = gross domestic product; PDR = People's Democratic Republic.

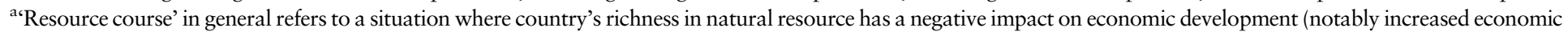
volatility), equality, social peace and governance.

'super profits' often linked to, but not always equating to, 'windfall profits' is used here to the kind of over the average profits which arise when companies can take advantage of a specific situation in their favor (such as a monopolistic or quasi-monopolistic situation or, for example, speculation riven rise in global commodity prices for extracting companies). 


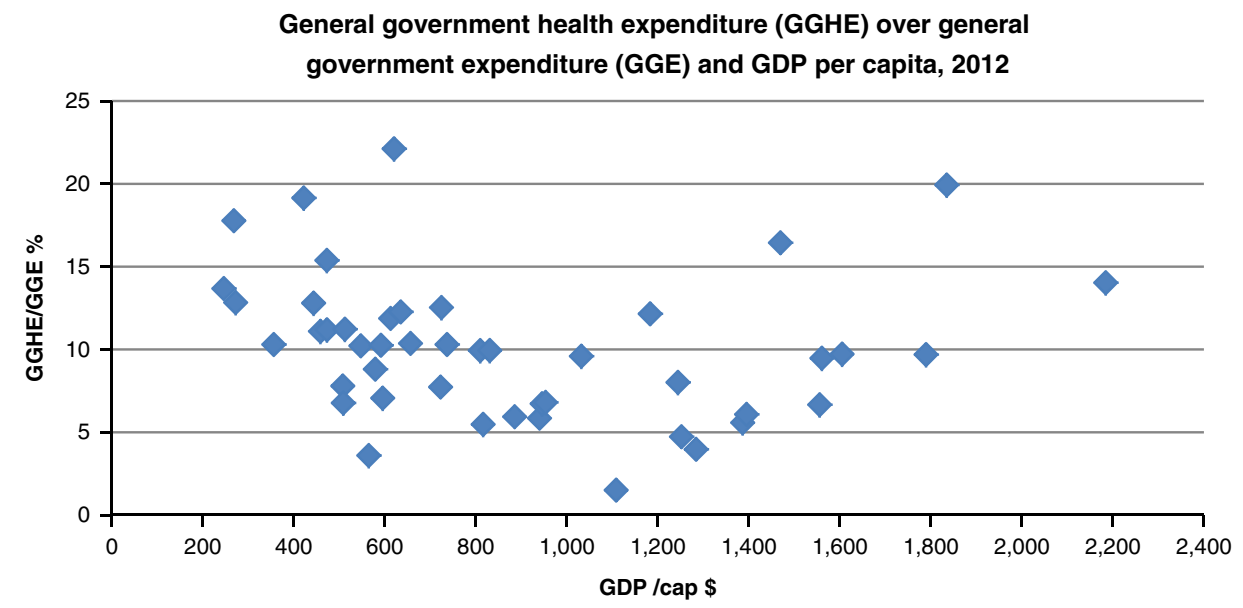

Figure 7. Priority given to health in government expenditure and gross domestic product (GDP) per capita.

Source: WHO, Global Health Expenditure Database.

Note: GGHE = general government health expenditure; GGE = general government expenditure.

1990s which had increased out-of-pocket expenditure to over $70 \%$ of THEs. In Chile, the government policy for effectively guaranteeing access to a set of services to the whole population (the AUGE plan) saw the share of GGHE in GGE rise from $12 \%$ in 2003 to $16 \%$ in 2010 . This corresponded to a period of strong economic growth so the level of government health spending per head more than tripled from \$134 per capita to \$456 [World Health Organization (WHO), 2012].

\section{Raising additional government revenues}

Workforce formalization and tax efficiency

The proportion of people working in the formal sector generally increases with GDP. This makes it theoretically easier for governments to collect income and company taxes, as well as indirect taxes like value added taxes (VAT) (World Bank, 2010). The rate at which governments can in practice increase their revenues will depend partly on the pace at which the formal sector develops, but it can also be influenced by strategies to increase the revenue base and to improve revenue collection efficiency.

There are several examples of countries that actively sought to increase the tax base or increase tax efficiency despite having large informal sectors. Uganda streamlined its business registration system and business registrations increased by $43 \%$ and revenue from registration fees by $40 \%$ (Sander, 2003). Indonesia's effort to simplify its tax system and to enforce collection was associated with an increase in tax revenues from 9.9 to $11.1 \%$ of non-oil GDP over 4 years. Health spending benefited disproportionately from the enhanced government revenues (WHO, 2010b). 
Turkey took measures to speed up the transition to a formal economy and to raise additional funds, including increasing auditing of workplaces (World Bank, 2010). Laws were amended to lower employment costs by introducing progressive social security contributions. Accompanied by stable economic growth, the informal employment rate fell from $33 \%$ in 2005 to $26 \%$ in 2011.

\section{Natural resource revenues}

According to the IMF, 20 of the 45 countries in sub-Saharan Africa are now significant exporters of natural resources (IMF, 2010b). In total, 10 already collected more public revenues from natural resources than from all other sources. Volatility in the prices of natural resources means volatility in revenues derived from them but carefully thought-out levies can increase government revenues substantially in many of these countries.

Botswana has long raised considerable government revenue from its diamond extraction industry, using much of it for social spending. The IMF has praised the sound management of diamond-related fiscal revenue (Basdevant, 2008), while Oxfam argued that the country has been something of an exception in trying to ensure that the revenues from exports of this natural resource are equitably distributed (Ross, 2001). In Papua New Guinea, tax proceeds from the country's biggest mine are channeled into the Sustainable Development Program, used for development programs including health. This mining revenue amounted to \$180 million yearly in 2008/2009 (or \$27 for every citizen). Lao People's Democratic Republic levies taxes on the sale of electricity to neighboring countries from a hydropower project. Around \$5.6 million ( $\$ 0.88$ per capita) was collected in 2010 and revenues are projected to rise to $\$ 80$ million per year over a 25 -year period (World Bank, 2011). Revenue allocation is focused on social and infrastructure spending, including health, which had received \$1 million by May 2011.

\section{Taxes on specific products}

A small levy on individual financial transactions is one option. Argentina, for example, has been taxing current account credits and debits since 2001, reportedly raising half as much as from total corporation income taxes between 2006 and 2008 (IMF, 2010a). In 2001 Brazil implemented a levy of $0.38 \%$ on a set of bank withdrawals, raising up to $\$ 20$ billion per year partly earmarked for health. Abolition of the levy in 2007 after political pressure from the financial sector resulted in shortfalls for the public health care system (WHO, 2010a). In 2009 Brazil introduced a new $2 \%$ levy on stock and bond transactions from outside the country.

Other examples are taxes on luxury goods through differential rates applied to existing taxes such as VAT, vehicle and property taxes or more general taxes on items such as mobile phones or their use. China has a luxury tax on products including yachts, imported watches and high-performance cars; Viet Nam has a special consumption tax on premium items such as luxury cars, yachts 
and private jets; and Indonesia has been taxing luxury consumption items for some time (Thrisk, 1997; China Daily, 2010; Reuters, 2010).

The HLTF noted that with 3.5 billion mobile phone users in the world, and with global revenues from post-paid mobile phone services high and rising (some $\$ 750$ billion per year), establishing a levy on the use of mobile phones would enlarge the tax base (High Level Task Force for Innovative International Financing, 2010). It estimated that a voluntary levy on mobile phone use could raise between $\$ 260$ million and $\$ 1.69$ billion annually. Uganda is already levying a targeted tax on mobile phone use and on handset sales. Taking into account the specific levies and other taxes on telecommunications products and services (such as VAT), the tax revenue from telecommunication companies amounted to $\$ 3.57$ billion in 2008, representing $9.5 \%$ of the country's total tax revenue (Butagira, 2009). In early 2015, Togo adopted a tax (25 francs CFA or 4 US $\not$ ) on incoming international calls; the revenue from this tax is earmarked for the national health insurance mechanism (Afrique It News, 2015).

Mobile phone use could also be taxed indirectly. Gabon has implemented a tax of $10 \%$ on the turnover of mobile phone companies. The revenue is earmarked for the national health insurance fund and covers the membership of people who cannot afford to contribute (Musango and Aboubacar, 2010). In 2009 the government collected 12 billion francs CFA, or US $\$ 25$ million, from it.

\section{Taxing unhealthy habits and products}

Taxes on products and behaviors that are unhealthy, frequently called 'sin taxes', are particularly interesting options for revenue raising from the health perspective. They reduce harmful consumption and improve health, reduce the need for costly treatment in the future, and raise additional revenue, some of which could be used for health (WHO Regional Office for South-East Asia, 2012).

Taxation on alcohol and tobacco products has proven effective in reducing consumption and improving health (Chaloupka et al., 2011; WHO, 2011). It is not new but many countries still apply low rates of taxation on these products, so there is considerable scope for increase. Some have already done so. In 2014 a presidential decree in Egypt increased tobacco taxes on the retail price of local and imported cigarettes to $50 \%$ and increased an additional levy to a range from EGP 1.75 to 2.75 per pack. These taxes are not earmarked for health although there is a longerstanding tax of 10 piastres $(\$ 0.018)$ per pack that is used to provide medical insurance for students. For fiscal year 2013/2014, the projected annual revenue from combined tobacco taxes was EGP 32 billion ( $\$ 4.2$ billion); if all this was channeled into health, it would represent a $25 \%$ increase in total government health expenditure. Moreover, it was calculated that the increase in tobacco taxation for 2010 alone would avert 190,000 deaths among current adult smokers. In the last decade Turkey has been actively increasing its tobacco taxes. Even before these recent increases, tobacco taxes represented $6.5 \%$ of all government revenues (Yurekli, 2010). 
Thailand has taken an innovative approach by taxing cheap alcoholic beverages at a rate based on alcohol content, and more expensive alcoholic beverages at a rate calculated on the value of the product. This assures a higher average tax rate, lower alcohol consumption and higher revenue (Sarntisart, 2012). The Philippines government enacted legislation in 2012 increasing alcohol taxation indexed to inflation. It calculated this would increase revenues by 31 billion pesos ( $\$ 760$ million) in 2012 and by 94 billion pesos (\$2.3 billion) in 2016 .

Taxes on unhealthy foods or drinks, such as those high in salt and sugar, are receiving increased attention, particularly in high-income countries where obesity and NCDs are growing health problems with considerable implications for health costs. Relatively small taxes on unhealthy foods, for example, soft drinks (soda) or salty snacks have been imposed in countries including Australia, Canada, Finland, France and Norway, and in some US states. In France a tax on soda was adopted in 2012 and it raised $€ 288$ million ( $\$ 250$ million) for the national health insurance (Le, 2011; Sénat, 2014). Given the increasing importance NCDs in low- and middle-income countries, this form of taxation is also an option there although revenues from taxing food items are believed to be more modest than for alcohol and tobacco and might lead to behavioral changes that reduce the revenues over time.

In general, revenue raising potential form taxation targeting unhealthy items and behavior will depend on the elasticity of the demand, that is, of how many the increased taxes will decrease the consumption of a specific item. The elasticities will vary between items, context and on how the tax will be practically implemented, so any policy on the 'sin taxes' will need to carefully factor in the effect of reduced consumption for any proposed measure.

\section{Earmarking taxes for health}

Ministries of finance generally do not favor hypothecation where taxes are earmarked for health because it reduces their flexibility to allocate funds to all sectors as needed. Public health advocates and ministries of health generally favor hypothecation. Furthermore, it is often argued that tax increases through earmarked taxation is more motivating for tax payers as they can directly understand the cause for which the tax is used. Djibouti and Guatemala earmark all their revenues from tobacco taxes for health, while Bulgaria, Mongolia, Qatar and Thailand allocate a proportion (WHO Regional Office for South-East Asia, 2012). Nepal and Tuvalu make a fixed money allocation to health for each item sold (WHO Regional Office for South-East Asia, 2012). In the Philippines, a proportion of the increased revenues from both tobacco and alcohol taxes is earmarked to fund the extension of the health insurance program to the poor (Official Gazette, 2012).

In the same vein, Ghana and Chile increased the VAT rate and specifically earmarked the additional VAT percentages to fund their health insurance 
programs (Witter and Garshong, 2009). Zimbabwe has since 1999 imposed an additional $3 \%$ tax on the income of formal sector employees as a national AIDS levy raising \$26 million in additional revenue in 2011, enabling 70,000 Zimbabweans to access antiretroviral therapy (UNAIDS, 2012).

The introduction of compulsory health insurance is effectively a tax specified for health. All citizens make an annual contribution (governments typically pay for people who cannot afford to contribute) to the insurance pool. A recent international review found that there is no conclusive evidence that the introduction of compulsory health insurance had reduced or increased available revenue for the health sector although generally it has reduced the financial problems poor households face when they need to pay out-of-pocket for health services (Spaan et al., 2012). Indeed, earmarked taxes in general may not raise additional money for health if governments simply reduce health funding from their other sources of revenue. In Kazakhstan, for example, the introduction of a payroll tax earmarked for health had an overall negative effect, because different levels of government reduced their general taxation-based budget allocations to health (Kutzin et al., 2010).

It is clear that, with or without hypothecation, there are many options for countries to increase domestic funding for health if they wish. The options provided here are not just theoretical possibilities, but options that at least one low- or middle-income country has already successfully introduced. Each country will need to consider which option would be most appropriate to it taking into account questions of (Tsounta, 2009):

- Adequacy and stability of the revenue raised;

- efficiency: that is, that it does not introduce major imbalances in the economy and/or distortions in behavior;

- equity and impact on the poor;

- ease and costs of collection;

- political acceptability.

We suggest a pragmatic approach. Where informal sectors are large, it is difficult to rely on direct income taxation to raise government revenue or to collect compulsory health insurance premiums, even if wage-based deductions offer the greatest potential for progressive taxation. Forms of indirect taxation, such as VAT, are simpler to collect and as a means to ensure that everyone contributes pending the growth of the formal sector. There are always concerns that taxes are distortionary - for example, it is often argued that taxes on mobile phones reduce their potential to be used for 'good' purposes such as the transmission of health data. A general concern is also that some forms of taxes are regressive, that is, that they overburden the poor and thus offsetting any pro-poor objective sought with the use of the money collected. But this is not always straight forward, for example, VAT can be more or less progressive or regressive depending on how it is implemented (what are the exclusion items, for example) (McIntyre and Kutzin, 
2011). At the end of the day, all taxes have some distortionary effect and some taxes can be regressive - governments need to consider all possible ways of raising additional funds for health and select among them comparing their ability to raise revenue with any distortionary effects.

Raising taxes and other direct contributions or redirecting government budgets (e.g. by reducing energy subsidies) is never going to be popular. However, if a government can demonstrate clear impact of these raises in terms of extending health coverage, these policies will most probably obtain popular support; this has already happened in countries such as Mexico, Thailand or Turkey.

\section{Voluntary contributions to bealth}

To this point, the focus has been on mechanisms for increasing government revenues and expenditure on health. Private philanthropy and leveraging corporate responsibility are additional options. These types of contribution will inevitably come with challenges of predictability and adequacy of the revenue collected, but they could supplement the mandatory systems discussed above.

Corporate social responsibility is one version. In many countries large corporations have been funding health care services for a broader population than the companies' employees. In Papua New Guinea, for example, mining companies have been funding and providing logistical and other support to health care facilities in their area of operation (Thomason, 2011). The South African Business Coalition on HIV/AIDS has been raising revenue for HIV/AIDS prevention and treatment and for health system strengthening from South African business, while also channeling donor resources to its projects (Feeley et al., 2009). In Malawi the national Business Coalition used its own funds to manage a mixed public-private project that expanded the distribution of antiretroviral therapies through private clinics at subsidized prices (Feeley et al., 2009).

Diaspora bonds are a possible source of revenue for countries with a large population that has emigrated to live in another country (the diaspora). They raise money for health from the diaspora, backed by government guarantees. The interest rates offered on the bonds are slightly lower than market rates in the hope that emigrants will buy them from patriotism, forgoing a small part of the return they could obtain on the open market. They are not yet widely used. India has issued several types of these bonds, and raised, net of repayment, US $\$ 11$ billion from three separate bond offers - in 1991, 1998 and 2000; while Sri Lanka and Lebanon have also used them, although no details of their net revenues are available (Ketkar and Ratha, 2009).

\section{Conclusions}

Global health expenditure has increased rapidly since 2000, even in the poorest countries. Domestic economic growth has facilitated a considerable part of the 
increased spending and, despite the substantial scale-up in DAH, domestic health spending remains the predominant source of finance in all but a handful of countries. Despite this, in the 46 vulnerable countries that were the focus of our analysis, only 12 might be able to reach the level of per capita spending needed to ensure even a very minimum set of key interventions from their own domestic sources just through economic growth. Increased, predictable flows of external funding for health are still needed, despite the economic downturn in the highincome countries.

That said, there is considerable scope for these countries to increase their own domestic funding for health, independent of economic growth. Many low- and middle-income countries have already taken steps to do this, and their diverse experiences were highlighted, providing both proof that it is possible and options for other countries to consider.

We recognize that raising additional domestic funding, the focus of this paper, is not sufficient in itself. WHO has suggested that between 20 and $40 \%$ of total health spending, or from $\$ 1.3$ to $\$ 2.6$ trillion, might be lost through waste, corruption and other forms of inefficiency (WHO, 2010b). Improving value for money, at the same time as raising additional funds, would provide a double boost to population health while at all times a careful eye needs to be kept on equity.

Many countries are adopting universal health coverage as their health sector development target - in line with the SDG goal 3 target 8. Funding the implementation of UHC policies will be crucial. Even when acknowledging the need for increasing efficiency, it is clear that the shortage in health expenditure, as described in this paper, is one of the main obstacles for many countries to effectively move toward UHC. Options exist to raise more revenue for health which can be politically and technically feasible, especially when the benefits are tangible and understood by the population. Moving toward the UHC objective is thus a question of policy choices and the political and administrative will to implement them.

\section{Acknowledgment}

This paper has benefited from comments and guidance from John-Arne Røttingen and Trygve Ottersen.

\section{References}

Afrique It News (2015), 'Les consommateurs contre la taxe sur les appels internationaux Entrants', 28 January, http://www.afriqueitnews.com/2015/01/28/togo-les-consommateurs-contretaxe-les-appels-internationaux-entrants/ [25 February 2015].

Basdevant, O. (2008), 'Are Diamonds Forever? Using the Permanent Income Hypothesis To Analyze Botswana's Reliance on Diamond Revenue, IMF Working Paper No. WP/08/08, International Monetary Fund, Washington, DC. 
Butagira, T. F. (2009), 'Uganda: Mobile Phone Tax - A Cash Cow or a Barrier to Development?' Blog Post, 20 November, http://panos.org.uk/features/uganda-mobile-phone-taxa-cash-cow-or-a-barrier-to-development/ [25 February 2015].

Chaloupka, F. J., K. Straif and M. E. Leon (2011), 'Effectiveness of tax and price policies in tobacco control', Tobacco Control, 20(3): 235-238.

China Daily (2010), 'China to Raise Luxury Taxes Further', China Daily, 21 March, http:// www.chinadaily.com.cn/china/2006-11/15/content_733992.htm [25 February 2015].

European Commission (2012), 'Eurostat Database', http://ec.europa.eu/eurostat/statistics-explained/ index.php/Evolution_of_government_expenditure_by_function [25 February 2015].

Feeley, F. G., P. Connelly and S. Rosen (2009), 'The Private Sector and HIV/AIDS in Africa: Recent Developments and Implications for Policy', in E. L. Lule. et al. (eds), The Changing HIV/AIDS Landscape: Selected Papers for The World Bank's Agenda for Action in Africa, 2007-2011, Washington, DC: World Bank, 267-293.

High Level Task Force for Innovative International Financing (2010), 'Mobile Phone Voluntary Solidarity Contribution (VSC)'. Task Force Fact Sheet, http://www. internationalhealthpartnership.net/fileadmin/uploads/ihp/Documents/Results__Evidence/ HAE_results__lessons/Taskforce\%20factsheet_-_mobile_phone_voluntary_solidarity_ contribution_EN.pdf [25 February 2015].

International Monetary Fund (IMF) (2010a), A Fair and Substantial Contribution by the Financial Sector: Final Report for the G-20, Washington, DC: IMF.

International Monetary Fund (IMF) (2010b), Economic Outlook: Sub-Saharan Africa. Sustaining Growth Amid Global Uncertainty, Washington, DC: IMF.

International Monetary Fund (IMF) (2011), 'Revenue Mobilization in Developing Countries', IMF, Washington, DC, www.imf.org/external/np/pp/eng/2011/030811.pdf [25 February 2015].

International Monetary Fund (IMF) (2014), 'World Economic Outlook Database', https:// www.imf.org/external/pubs/ft/weo/2016/01/weodata/index.aspx [25 February 2015].

Ketkar, S. and D. Ratha (2009), 'Development Finance Via Diaspora Bonds', in S. Ketkar and D. Ratha (eds), Innovative Financing for Development, Washington, DC: World Bank, 59-78.

Kutzin, J., C. Cashin and M. Jakab (eds) (2010), Implementing Health Financing Reform: Lessons From Countries in Transition, Brussels: European Observatory on Health Systems and Policies.

Le, M. (2011), 'Le taxe soda ne fait pas le poids'. 26 August, http://www.lemonde.fr/economie/ article/2011/08/26/la-taxe-soda-ne-fait-pas-le-poids_1563734_3234.html [25 February 2015].

McIntyre, D., F. Meheus and J.-A. Røttingen (2017), 'What level of domestic government health expenditure should we aspire to for universal health coverage?', Health Economics, Policy and Law, 12(2): 125-137.

McIntyre, D. and J. Kutzin (2011), 'Revenue Collection and Pooling Arrangements in Health System Financing', in R. Smith and K. Hanson (eds), Health Systems in Low- and Middle-Income Countries, Oxford: Oxford University Press, 77-101.

Mladovsky, P., D. Srivastava, J. Cylus, M. Karanikolos, T. Evetovits, S. Thomson and M. Mckee (2012), Health Policy Responses to the Financial Crisis in Europe, Copenhagen: World Health Organization, on behalf of the European Observatory on Health Systems and Policies.

Musango, L. and I. Aboubacar (2010), 'Assurance Maladie Obligatoire au Gabon: un atout pour le bien-être de la population', World Health Report 2010 Background Paper, WHO, Geneva. 
Official Gazette (2012), 'Sin taxes', Office of the President of the Philippines, http://www.gov. ph/sin-tax/ [25 February 2015].

Ottersen, T. and O. F. Norheim, on behalf of the World Health Organization Consultative Group on Equity and Universal Health Coverage (2014), 'Making fair choices on the path to universal health coverage', Bulletin of the World Health Organization, 92: 389-389.

Reuters (2010), 'Bulgaria to Introduce "Luxury" Tax to Fight Crisis', 21 March, http://in. reuters.com/article/idINIndia-47098920100321 [25 February 25 2015].

Ross, M. (2001), Extractive Sectors and the Poor, Boston, MA: Oxfam America.

Sander, C. (2003), Less is More: Better Compliance and Increased Revenues by Streamlining Business Registration in Uganda, London: Bannock Consulting.

Sarntisart, I. (2012), 'Alcohol excise taxation in Thailand: more than a simple one', Addiction, 107(8): 1387.

Savedoff, W. D. (2007), 'What should a country spend on health care', Health Affairs, 26(4): 962-970.

Sénat (2014), 'Fiscalité et santé publique: état des lieux des taxes comportementales', http://www.senat.fr/rap/r13-399/r13-3997.html [25 February 2015].

Spaan, E., J. Mathijssen, N. Tromp, F. McBain, A. Ten Have and R. Baltussen (2012), 'The impact of health insurance in Africa and Asia: a systematic review', Bulletin of the World Health Organization, 90: 685-692A.

Thomason, J. (2011), 'PNG Mineral Boom: Harnessing the Extractive Sector to Deliver Better Health Outcomes', Discussion Paper No. 2, Australian National University.

Thrisk, W. (ed.) (1997), Tax Reform in Developing Countries, Washington, DC: World Bank.

Tien, T. V. (2011), A Health Financing Review of Viet Nam With a Focus on Social Health Insurance, Geneva: WHO.

Tsounta, E. (2009), Universal Health Care 101: Lessons from the Eastern Caribbean and Beyond, Washington, DC: International Monetary Fund.

UNAIDS (2012), 'Zimbabwe Levy Generates New Resources for Treatment: Feature Story', http:// www.unaids.org/en/resources/presscentre/featurestories/2012/february/20120221zimbabwe [25 February 2015].

World Health Organization (WHO) (2010a), 'Brazil's march towards universal coverage', Bulletin of the World Health Organization, 88(9): 646-647.

World Health Organization (WHO) (2010b), World Health Report 2010: Health Systems Financing: The Path to Universal Coverage, Geneva: WHO.

World Health Organization (WHO) (2011), Global Status Report on Alcohol and Health, Geneva: WHO.

World Health Organization (WHO) (2012), Chile: Improving Access, Quality and Financial Protection, Geneva: WHO.

WHO Regional Office for Africa (2011), 'The Abuja Declaration: Ten Years On'. WHO Regional Office for Africa, Brazzaville, http://www.who.int/healthsystems/publications/ abuja_declaration/en/index.html. [25 February 2015].

WHO Regional Office for South-East Asia (2012), Tobacco Taxation and Innovative HealthCare Financing, New Delhi: WHO Regional Office for South-East Asia.

Witter, S. and B. Garshong (2009), 'Something old or something new? Social health insurance in Ghana', BMC International Health and Human Rights, 920.

World Bank (2010), Turkey, Country Economic Memorandum: Informality: Causes, Consequences, Policies, Washington, DC: World Bank.

World Bank (2011), 'Nam Theun 2 Factsheet', http://www.worldbank.org/en/news/feature/ 2011/05/11/latest-nam-theun-2-factsheet [25 February 2015]. 
Xu, K. and P. Saksena (2011), 'The Determinants of Health Expenditure: A Country-Level Panel Data Analysis'. World Health Organization and Results for Development Institute, Working Paper of the Results for Development Institute.

Yurekli, A. (2010), The Economics of Tobacco and Tobacco Taxation in Turkey, Paris: International Union Against Tuberculosis and Lung Disease.

\section{Appendix 1}

The 46 countries included in the analysis

\begin{tabular}{lll}
\hline \hline WHO African Region & 18. Malawi & 34. Pakistan \\
1. Benin & 19. Mali & 35. Yemen \\
2. Burkina Faso & 20. Mauritania & WHO European Region \\
3. Burundi & 21. Mozambique & 36. Kyrgyzstan \\
4. Central African Republic & 22. Niger & 37. Tajikistan \\
5. Chad & 23. Nigeria & 38. Uzbekistan \\
6. Comoros & 24. Rwanda & WHO South-East Asia Region \\
7. Côte d'Ivoire & 25. São Tomé and Principe & 39. Bangladesh \\
8. Democratic Republic of the Congo & 26. Senegal & 40. Myanmar \\
9. Eritrea & 27. Sierra Leone & 41. Nepal \\
10. Ethiopia & 28. Togo & WHO Western Pacific Region \\
11. Gambia & 29. Uganda & 42. Cambodia \\
12. Ghana & 30. United Republic of Tanzania & 43. Lao People's Democratic Republics \\
13. Guinea & 31. Zambia & 44. Papua New Guinea \\
14. Guinea-Bissau & WHO Region of the Americas & 45. Solomon Islands \\
15. Kenya & 32. Haiti & 46. Viet Nam \\
16. Liberia & WHO Eastern Mediterranean Region \\
17. Madagascar & 33. Afghanistan & \\
\hline \hline
\end{tabular}

